\title{
The Relationships between Leisure Satisfaction, Job Performance, and Life Satisfaction: A Sample of Private Sector Employees in Turkey
}

\author{
Emrah SERDAR $^{1}$ Mehmet DEMIREL ${ }^{2}$ Cihan AYHAN $^{3}$
}

\begin{abstract}
This study aimed to describe the relationships between leisure satisfaction, job performance, and life satisfaction among private-sector employees. The study sample consisted of 347 employees, 158 males, and 189 females, working in a private company in Istanbul. The participants were selected using a purposeful sampling method. The data collection tools included the "Leisure Satisfaction Scale"; the "Job Performance Scale", and "Life Satisfaction Scale". The data were analyzed using independent t-test, ANOVA, MANOVA, and Pearson Correlation analysis. The analysis results showed no significant difference between the Life-SS and Leisure-SS scores by gender, but there was a difference in the JPS scores. No significant difference was measured in any scales by marital status. There was a significant statistically meaningful difference between the Life-SS and JPS scores by working types, but no difference in the Leisure-SS scores. There was a difference between the Life-SS and JPS scores; the difference in the Leisure-SS scores was not significant. There was a positive and low-level relationship between JPS and Life-SS. Similarly, a positive and low-level relationship was found between the "Psychological," "Educational" and "Social" sub-dimensions of Leisure-SS and Life-SS. However, there was no relationship between the sub-dimensions of JPS and Leisure-SS. In conclusion, there were meaningful differences in all scale scores by specific socio-demographic characteristics; there was a positive correlation between the "Psychological," "Educational" and "Social" sub-dimensions of Leisure-SS and the Life-SS, and that there was no relationship between Leisure-SS, Life-SS, and JPS. As a result, it can be said that as individuals' job performance and leisure time satisfaction increase, their life satisfaction also increases.
\end{abstract}

Keywords: Leisure satisfaction, life satisfaction, job performance

\section{Serbest Zaman Doyumu, İş Performansı ve Yaşam Doyumu Arasındaki İlişki: Türkiye'deki Özel Sektör Çalışanları Örneği}

$\ddot{\partial} z$

$\mathrm{Bu}$ araştırmanın amacı, özel sektörde çalışan bireylerin serbest zaman doyum düzeyleri, iş performansları ve yaşam doyumları arasındaki ilişsinin belirlenmesidir. Araştırmanın örneklemini, İstanbul ilinde bulunan, özel sektörde faaliyet gösteren bir şirkette çalışan ve amaçlı örneklemi yöntemi ile seçilen 158 erkek ve 189 kadın olmak üzere toplamda 347 kişi oluşturmuştur. Veri toplama aracı olarak, "Serbest Zaman Doyum Ölçeği", "İ̧sgören Performans Ölçeği" ile "Yaşam Doyumu Ölçeği" kullanılmıştır. Verilerin analizinde ise, bağımsız ttesti, ANOVA, MANOVA ve Pearson Korelasyon analizleri kullanılmıştır. Cinsiyet değişkenine göre, katılımcıların YDÖ ile SZDÖ puanları arasında anlamlı farklılık bulunmazken, IPÖ puanları arasında farklılık vardır. Medeni duruma göre katılımcıların YDÖ, İPÖ ile SZDÖ puanları arasında farklılık saptanamamıştır. Bireylerin çalışma şekillerine göre YDÖ ile İPÖ puanları arasında farklılık varken, SZDÖ puanları arasında farklılık görülmemektedir. İPÖ ile YDÖ arasında pozitif ve düşük düzeyde bir ilişki, SZDÖ'nın "Psikolojik", "Eğitimsel" ve "Sosyal" alt boyutları ile YDÖ arasında pozitif ve düşük düzeyde bir ilişki olduğu belirlenmiştir. İPÖ ile SZDÖ'nın alt boyutları arasında ilişki olmadığı saptanmıştır. Sonuç olarak, bireylerin sosyo-demografik özelliklerine göre SZDÖ, YDÖ ile İPÖ düzeylerinin farklılık gösterdiği ve İPÖ ile YDÖ ve SZDÖ arasında ilişki olmadığı, SZDÖ'nın "Psikolojik", "Eğitimsel" ve "Sosyal" alt boyutları ile YDÖ arasında pozitif yönde bir ilişki olduğu saptanmıştır. Sonuç olarak, bireylerin iş performansları ve serbest zaman doyumları arttıkça yaşam doyumlarının da artış gösterdiği söylenebilir.

Anahtar Kelimeler: Serbest zaman doyumu, yaşam doyumu, iş performansı

${ }^{1}$ Istanbul University-Cerrahpaşa, Faculty of Sport Sciences, Istanbul, Turkey serdar-emrah@hotmail.com https://orcid.org/0000-0003-2438-6748

${ }^{2}$ Necmettin Erbakan University, Faculty of Tourism, Konya, Turkey mehmetdemirel78@gmail.com, https://orcid.org/00000003-1454-022X

${ }^{3}$ Sakarya University of Applied Sciences, Faculty of Sport Sciences, Sakarya, Turkey cihanayhan@subu.edu.tr https://orcid.org/ 0000-0002-7633-1389 


\section{INTRODUCTION}

Leisure is an essential part of life, and many people believe that leisure activities can help them cope with job-related problems (Iwasaki \& Mannell, 2000; Tsaur et al., 2012). Leisure is characterized by the enjoyable activities that individuals voluntarily engage in to withdraw from work and other responsibilities (Pressman et al., 2009; Eifert et al., 2019). In other words, leisure activities are non-work activities performed voluntarily and with recreational purposes (Hills \& Argyle, 1998; Holder et al., 2009; Shin \& You, 2013). Besides, it is suggested that engaging in leisure activities promotes general well-being and socialization, increases life quality by providing them with opportunities to show their talents, realize their potentials, and experience various emotions (Dattilo \& Schleien, 1994; Azaiza et al., 2011). People get different levels of benefit and satisfaction from different leisure activities (Yurcu et al., 2018; Serdar \& Demirel, 2020). Thus, Beard and Ragheb (1980) describe leisure satisfaction as the positive perceptions or emotions that an individual creates and elicits from leisure activities.

It is described as the degree of satisfaction from leisure experiences (Walker \& Ito, 2017). Kuykendall et al. (2017) also underlined the overall satisfaction with leisure experiences (Rosa et al., 2019). In other words, Ragheb and Tate (1993) assume leisure satisfaction as positive outcome resulting from participation in leisure activities (Kim et al., 2015). Beard and Ragheb (1980) determined six dimensions of leisure satisfaction: psychological, educational, social, relaxational, physiological, and aesthetic (Lin \& Yu, 2015). The psychological dimension refers to mental benefits such as emitting enjoyment, expressing individuality, and developing selfconfidence. The relaxational dimension refers to relieving stress and promoting emotional well-being (Choi \& Fu, 2015). The educational dimension offers individuals opportunities to try new things, learn about themselves, others, and their surroundings (Çelik et al., 2014). The physiological dimension is related to improving physical fitness and being healthy. The social dimension refers to rewarding relationships with others (Cheng et al., 2010). The aesthetic dimension is about the sanitation and design of recreational places where individuals engage in leisure activities (Choi \& Yoo, 2017).

Life satisfaction is generally conceptualized as a sense of well-being stemming from satisfaction or dissatisfaction with living spaces (Ferrans, 1996; Liang et al., 2013). Edginton et al. (2005) define life satisfaction as an assessment of life by love, happiness, and well-being (Cho et al., 2017). Individuals assess their life satisfaction considering emotional experiences. Positive and negative emotions influence life satisfaction (Cho, 2019; Iyer \& Jetten, 2011; Kuppens et al., 2008). Individuals with high life satisfaction are also advantageous in terms of professional success. In this sense, high life satisfaction is associated with good job performance, high career satisfaction, increased organizational commitment, and decreased intent to quit the job (Erdoğan et al., 2012; Antaramian, 2017). Besides, it was observed that general life satisfaction is characterized by satisfaction from physical health, working life, family, and leisure (Janet et al., 1999; Argan et al., 2018). Job performance is characterized by employees' consistent behaviors that contribute to organizational goals (Jex \& Thomas, 2003; Mulki et al., 2008). According to Roe (1999), job performance is an outcome and process in which individuals collectively attempt to achieve specific organizational goals (Alessandri et al., 2015). In other words, one's ability to carry out their job's tasks and descriptions refer to fulfilling the organizational responsibilities (Anitha, 2014; Chen et al., 2014; Prentice \& Thaichon, 2019). Borman and Motowidlo (1997) discussed job performance in two dimensions: contextual and task performance. Task performance refers to the accomplishment of organizational tasks by employees traditionally and formally. Contextual performance includes voluntary behaviors (Bozer \& Yanık, 2020).

The researches in the literature indicated a meaningful relationship between leisure satisfaction and life satisfaction (Ağyar, 2014; Chick et al., 2014; Chick et al., 2016; Korotkov et al., 2011; Payne \& Zabriskie, 2014; Smith et al., 2009; Aslan and Cansever, 2016). However, there are a limited number of studies examining the relationship between 
leisure satisfaction and job performance. Therefore, the study aimed to determine the relationship between leisure satisfaction, job performance, and life satisfaction of individuals working in the private sector.

\section{METHOD}

\section{Research Model}

A relational survey model was used in the research. In the model, questions such as the degree of difference between variables are clarified with relational patterns (Gürbüz \& Şahin, 2016).

\section{Research Group}

The sample consisted of 347 employees in a private company in Istanbul, 158 males $\left(\right.$ Mean $\left._{\text {age }}=34.86 \pm 6.41\right)$ and 189 females $\left(\right.$ Mean $\left._{\text {age }}=33.64 \pm 5.61\right)$, who were selected using a purposeful sampling method. $65.7 \%$ of the participants were "Married," $71.5 \%$ were "University Graduates," 41.5\% worked for "46 years" in the company, 32\% had "6-10 hours" of weekly leisure, and $83 \%$ had "Average" income.

\section{Data Collection and Tools}

Regarding participation in the research, necessary permissions were obtained from the company where the data will be collected. The relevant questionnaires were administered to the participants individually at their workplaces, and sensitivity was shown to answer the questionnaires correctly. Before the data collection tools were presented to the participants, a brief briefing was given about the purpose and importance of the research. The data were collected by the researcher by face-to-face survey technique between 15.01.2021 and 15.02.2021.

\section{Leisure Satisfaction Scale (Leisure-SS):}

The scale was developed by Beard and Ragheb (1980) to assess leisure satisfaction and adapted into Turkish by Gökçe and Orhan (2011). The 5-point Likert type scale includes 24 items and six sub-scales: "Psychological" (4 Items), "Educational" (4 Items), "Social" (4 Items), "Physiological" (4 Items),
"Relaxational" (4 Items), and "Aesthetics" (4 Items). The Cronbach alpha coefficient of the original scale was .90 . It was .77 for the psychological, .77 for the educational, .76 for the social, .79 for the physiological, .80 for the relaxational, and .79 for the aesthetic subscales. For the current study, it was measured .94 for psychological, .94 for educational, .94 for social, .95 for physiological, .94 for relaxational and .93 for aesthetics sub-scales. It is a 24-item tool scored on a 5-point Likert scale ranging from 1 (Almost Not True) to 5 (Almost Always True).

\section{Job Performance Scale (JPS):}

It is a one-dimensional and 4-item instrument scored on a 5-point Likert scale ranging from 1 (Strongly Disagree) to 5 (Strongly Agree) that assess the job performance levels. It was developed by Kirkman and Rosen (1999) and adapted into Turkish by Çöl (2008). The original scale's internal consistency coefficient was 0.82 , and it was measured 0.94 for the current study.

\section{Life Satisfaction Scale (Life-SS):}

The scale was developed by Diener et al. (1985) and adapted to Turkish by Yetim (1993). It is a one-dimensional scale consisting of five items. Items are ranged from 1 (Strongly Disagree) to 7 (Strongly Agree). The internal consistency coefficient of the original scale was 0.86 . It was measured as 0.94 in the current study.

\section{Statistical Analysis}

The data were analyzed using the SPSS 20.0 package program. The percentage and frequency methods were applied to show the distribution of personal information. To determine whether the variables exhibit a normal distribution, the normality test was tested by considering the criteria of skewness and kurtosis values being within the range of \pm 2 (George ve Mallery, 2016). The results indicated a normal distribution. Thus, independent t-test, One-way ANOVA, MANOVA, and Pearson correlation analysis were used in the data analysis. 
Serdar E., Demirel M. \& Ayhan C. (2021). The Relationships between Leisure Satisfaction, Job Performance, and Life Satisfaction. International Journal of Recreation and Sport Science, 5(1); 72-82.

\section{FINDINGS}

Table 1. Distribution of scale scores

\begin{tabular}{cccccccc}
\hline \multirow{2}{*}{ Variables } & Scale Sub-Dimensions & $\begin{array}{c}\text { Item } \\
\text { Numbers }\end{array}$ & $\mathbf{n}$ & Mean & Sd. & Sk. & Kr. \\
\hline \multirow{3}{*}{$\begin{array}{c}\text { Leisure } \\
\text { Satisfaction } \\
\text { Scale }\end{array}$} & Psychological & 4 & 347 & 3.28 & 0.79 & -0.39 & 0.23 \\
\cline { 2 - 8 } & Educational & 4 & 347 & 3.28 & 0.80 & -0.24 & 0.21 \\
\cline { 2 - 8 } & Social & 4 & 347 & 3.23 & 0.82 & -0.25 & 0.22 \\
\cline { 2 - 8 } & Relaxational & 4 & 347 & 3.39 & 0.87 & -0.36 & -0.14 \\
\cline { 2 - 8 } & Physiological & 4 & 347 & 3.24 & 0.83 & -0.19 & -0.20 \\
\hline JPS & Aesthetic & 4 & 347 & 3.37 & 0.85 & -0.31 & 0.15 \\
\hline Life-SS & Job Performance & 4 & 347 & 4.11 & 1.13 & -1.09 & -0.28 \\
\hline Life Satisfaction & 5 & 347 & 4.78 & 1.38 & -0.93 & -0.23 \\
\hline
\end{tabular}

Sk.: Skewness; Kr.: Kurtosis

As seen in Table 1, the highest mean of Leisure-SS was in the "relaxational" (3.39), and the lowest mean was in the "social" (3.23) sub-dimension. The mean score of the Life-SS was 4.11 , and it was measured at 4.78 for LifeSS.

Table 2. Analysis of Scale Scores by Gender

\begin{tabular}{llccc}
\hline & \multicolumn{2}{l}{ Male $(\boldsymbol{n = 1 5 8})$} & \multicolumn{2}{l}{ Female $(\boldsymbol{n}=\mathbf{1 8 9})$} \\
\hline Variables & \multicolumn{3}{l}{ Mean } & Sd. \\
\hline & Mean & Sd. & 4.72 & 1.39 \\
\hline Life-SS & 4.85 & 1.37 & 4.40 & 0.93 \\
\hline JPS & 3.76 & 1.24 & & \\
\hline Leisure Satisfaction Scale & & & 3.26 & 0.82 \\
\hline Psychological & 3.30 & 0.77 & 3.28 & 0.86 \\
\hline Educational & 3.29 & 0.73 & 3.22 & 0.83 \\
\hline Social & 3.25 & 0.80 & 3.41 & 0.90 \\
\hline Relaxational & 3.36 & 0.83 & 3.19 & 0.88 \\
\hline Physiological & 3.31 & 0.77 & 3.38 & 0.87 \\
\hline Aesthetic & 3.37 & 0.83 & &
\end{tabular}

Table 2 shows the analysis results by gender. In this sense, there was no significant difference in Life-SS scores by gender $(\mathrm{t}=$ .896 ; p> 0.05). However, a significant difference was found in JPS scores by gender $(\mathrm{t}=-5.430 ; \mathrm{p}<0.05)$. Job performance levels of females were higher than males. MANOVA analysis results revealed no significant impact of gender on the sub-dimensions of Leisure-SS $\left[\lambda=0.974, \quad F^{(6,340)}=1.491 ; \quad \mathrm{p}>0.05\right]$.

Table 3. Analysis of Scale Scores by Marital Status

\begin{tabular}{|c|c|c|c|c|}
\hline \multirow{2}{*}{ Variables } & \multicolumn{2}{|c|}{ Married $(n=228)$} & \multicolumn{2}{|c|}{ Single $(n=119)$} \\
\hline & Mean & Sd. & Mean & Sd. \\
\hline Life-SS & 4.84 & 1.36 & 4.66 & 1.43 \\
\hline JPS & 4.16 & 1.08 & 4.00 & 1.22 \\
\hline \multicolumn{5}{|c|}{ Leisure Satisfaction Scale } \\
\hline Psychological & 3.23 & 0.80 & 3.37 & 0.79 \\
\hline Educational & 3.25 & 0.83 & 3.36 & 0.74 \\
\hline Social & 3.20 & 0.82 & 3.29 & 0.81 \\
\hline Relaxational & 3.37 & 0.86 & 3.42 & 0.89 \\
\hline Physiological & 3.20 & 0.83 & 3.32 & 0.84 \\
\hline Aesthetic & 3.32 & 0.83 & 3.48 & 0.89 \\
\hline
\end{tabular}


As seen in Table 3, there was no significant difference in the Life-SS scores by marital status $(\mathrm{t}=1.104 ; \mathrm{p}>0.05)$. Similarly, no significant difference was found in JPS scores by marital status $(\mathrm{t}=1.259 ; \mathrm{p}>0.05)$. MANOVA analysis results showed that the main effect of the marital status on the subdimensions of Leisure-SS was not significant, and there was also no significant difference in the sub-dimensions level $\left[\lambda=0.980, \mathrm{~F}_{(6,340)}\right.$ $=1.129 ; \mathrm{p}>0.05]$.

Table 4. Analysis of Scale Scores by Labor Types

\begin{tabular}{lcccc}
\hline Variables & \multicolumn{2}{c}{ Regular labor $(\boldsymbol{n}=\mathbf{2 4 0})$} & \multicolumn{2}{c}{ Contract labor $(\boldsymbol{n}=\mathbf{1 0 7})$} \\
& Mean & Sd. & Mean & Sd. \\
\hline Life-SS & 4.92 & 1.34 & 4.45 & 1.43 \\
\hline JPS & 4.29 & 1.06 & 3.70 & 1.18 \\
\hline Leisure Satisfaction Scale & & & & \\
$\quad$ Psychological & 3.31 & 0.76 & 3.19 & 0.86 \\
$\quad$ Educational & 3.27 & 0.78 & 3.31 & 0.84 \\
$\quad$ Social & 3.24 & 0.79 & 3.23 & 0.87 \\
$\quad$ Relaxational & 3.37 & 0.84 & 3.42 & 0.94 \\
$\quad$ Physiological & 3.24 & 0.82 & 3.27 & 0.85 \\
$\quad$ Aesthetic & 3.35 & 0.81 & 3.42 & 0.93 \\
\hline
\end{tabular}

Table 4 presents the analysis results by labor types. A significant difference was found in the Life-SS scores by labor types $(\mathrm{t}=2.979 ; \mathrm{p}$ $<0.05)$. Similarly, a significant difference was found in JPS scores by labor type $(\mathrm{t}=4.618$; $\mathrm{p}$ $<0.05)$. It was determined that life satisfaction and job performance of regular laborers were higher than singles. MANOVA analysis results revealed no meaningful effect of the labor types on the sub-dimensions of Leisure-SS $[\lambda=$ $\left.0.971, \mathrm{~F}_{(6,340)}=1.683 ; \mathrm{p}>0.05\right]$.

Table 5. Analysis of Scale Scores by Weekly Leisure

\begin{tabular}{|c|c|c|c|c|c|c|c|c|}
\hline \multirow{2}{*}{ Variables } & \multicolumn{2}{|c|}{$\begin{array}{c}\text { 1-5 Hours } \\
(n=88)\end{array}$} & \multicolumn{2}{|c|}{$\begin{array}{l}\text { 6-10 Hours } \\
(n=111)\end{array}$} & \multicolumn{2}{|c|}{$\begin{array}{l}\text { 11-15 Hours } \\
(n=104)\end{array}$} & \multicolumn{2}{|c|}{$\begin{array}{l}16 \text { Hours and More } \\
\quad(n=44)\end{array}$} \\
\hline & Mean & Sd. & Mean & Sd. & Mean & Sd. & Mean & Sd. \\
\hline Life-SS & 4.71 & 1.27 & 4.81 & 1.41 & 4.87 & 1.40 & 4.63 & 1.50 \\
\hline JPS & 4.11 & 1.13 & 4.10 & 1.13 & 4.21 & 1.08 & 3.84 & 1.22 \\
\hline \multicolumn{9}{|c|}{ Leisure Satisfaction Scale } \\
\hline Psychological & 3.21 & 0.88 & 3.36 & 0.74 & 3.26 & 0.74 & 3.23 & 0.87 \\
\hline Educational & 3.23 & 0.91 & 3.34 & 0.74 & 3.25 & 0.73 & 3.32 & 0.88 \\
\hline Social & 3.16 & 0.97 & 3.24 & 0.72 & 3.23 & 0.75 & 3.38 & 0.86 \\
\hline Relaxational & 3.31 & 0.97 & 3.49 & 0.81 & 3.36 & 0.78 & 3.36 & 1.01 \\
\hline Physiological & 3.26 & 0.90 & 3.30 & 0.79 & 3.26 & 0.77 & 3.10 & 0.93 \\
\hline Aesthetic & 3.31 & 0.94 & 3.45 & 0.78 & 3.36 & 0.83 & 3.35 & 0.90 \\
\hline
\end{tabular}

Table 5 shows the analysis results by weekly leisure. In this sense, there was no significant difference in the Life-SS scores by weekly leisure of the participants ( $f=.420 ; p>0.05$ ). No significant difference was also found in
JPS scores by weekly leisure $(\mathrm{t}=1.099 ; \mathrm{p}$ > $0.05)$. MANOVA analysis results revealed that the main effect of the weekly leisure on the sub-dimensions of Leisure-SS was not significant $\left[\lambda=0.955, \mathrm{~F}_{(18,956)}=.881 ; \mathrm{p}>0.05\right]$. 
Serdar E., Demirel M. \& Ayhan C. (2021). The Relationships between Leisure Satisfaction, Job Performance, and Life Satisfaction. International Journal of Recreation and Sport Science, 5(1); 72-82.

Table 6. Analysis Results between Scale Scores

\begin{tabular}{|c|c|c|c|c|c|c|c|c|c|}
\hline & Variables & (1) & (2) & (3) & (4) & (5) & (6) & (7) & (8) \\
\hline & Life Satisfaction (1) & 1 & & & & & & & \\
\hline & Job Performance (2) & $.157^{* *}$ & 1 & & & & & & \\
\hline \multirow{6}{*}{ 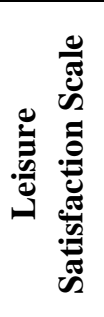 } & Psychological (3) & $.219^{* *}$ & .090 & 1 & & & & & \\
\hline & Educational (4) & $.112^{* *}$ & .034 & $.769^{* *}$ & 1 & & & & \\
\hline & Social (5) & $.115^{*}$ & 034 & $.681^{* *}$ & $.793^{* *}$ & 1 & & & \\
\hline & Relaxational (6) & .057 & .035 & $.670^{* *}$ & $.711^{* *}$ & $.767^{* *}$ & 1 & & \\
\hline & Physiological (7) & .104 & .023 & $.593^{* *}$ & $.626^{* *}$ & $.624^{* *}$ & $.692^{* *}$ & 1 & \\
\hline & Aesthetic (8) & .068 & .048 & $.630^{* *}$ & $.661^{* *}$ & $.695^{* *}$ & $.792^{* *}$ & $.755^{* *}$ & 1 \\
\hline
\end{tabular}

According to the Pearson Correlation analysis results in Table 6 , there was a positive and low-level relationship between Job Performance and Life Satisfaction, and between the "Psychological," "Educational,"

\section{DISCUSSION AND CONCLUSION}

The gender's main effect on leisure satisfaction levels was not significant, and there was no significant difference in the subdimensions, which did not overlap with the findings of Ngai (2005), Serdar and Ay (2016), Serdar et al. (2018), Chun et al. (2012), Celik et al. (2014), and Muzindutsi and Masango (2015). However, Yaşartürk and Bilgin (2019) and Tian et al. (2020) found similar results. In light of the studies in the literature, it is suggested that the differences between study findings can stem from using different sample groups. Although men's life satisfaction levels were higher than women's, statistically significant no difference was found, which was also found by Çakır et al. (2016), Drakou et al. (2006). Thus, it can be implied that gender is not an important factor affecting life satisfaction. A significant difference was found in participants' job performance levels by gender. In other words, women had higher job performance levels than men. In their study, Türkoğlu, and Yurdakul (2017), Dhani and Sharma (2017) reached similar results.

The main effect of the participants' marital status on their leisure satisfaction was not significant, and there was no significant difference in the sub-dimensions. In this sense, leisure satisfaction levels did not differ by and "Social" sub-dimensions of Leisure Satisfaction and Job Performance. However, there was no statistically significant relationship between the sub-dimensions of JPS and Leisure-SS.

being single or married. In light of the findings, the findings of Ngai (2005), Koç and Er (2020), and Yaşartürk et al. (2018) were in line with the results of the current study. It can be suggested that marital status is not an influential variable in determining leisure satisfaction. No statistically significant difference was found in the life satisfaction of married and single individuals. However, Drakou et al. (2006) determined that the married coaches' life satisfaction was higher than the single or divorced coaches, which was a different finding from the current ones. The differences between study results can be due to the use of different research groups. No statistically significant difference was found in participants' job performance levels by marital status. In other words, although the job performance of married participants was higher than singles, the difference was not statistically significant. The study results of

Türkoğlu and Yurdakul (2017) overlapped with the current finding. No significant difference was found in leisure satisfaction levels by labor type. Although the leisure satisfaction levels of the contract laborers were high, the difference was not statistically significant. It might stem from that labor type was not an indicator of leisure satisfaction. 
A significant difference was found in life satisfaction by labor types. In other words, regular laborers' life satisfaction level in a workplace was higher than contract laborers. It can be interpreted as the fact that regular laborers are less likely to experience work-liferelated problems than contract laborers. A significant difference was seen in job performances by labor type. It was in favor of regular laborers. Thus, it can be suggested that labor types of influence job performance.

The main effect of weekly leisure on leisure satisfaction was not significant. There was also no significant difference in the subdimensions. This finding was also proved by Serdar and Demirel (2020). In other words, the weekly leisure of participants did not affect their leisure satisfaction. Although the life satisfaction levels of those with 11-15 hours of weekly leisure were high, this difference was not statistically significant. Hence, there was no difference in life satisfaction of participants by their weekly leisure.

Similarly, although the work performance of those with 11-15 hours of weekly leisure was high, no significant difference was obtained, which can be interpreted as the weekly leisure did not affect their job performance.

There was a positive and low-level relationship between job performance and life satisfaction. In this sense, as job performance increases, so does the life satisfaction level. Besides, there was a positive and low-level relationship between the "Psychological," "Educational" and "Social" sub-dimensions of leisure satisfaction and life satisfaction levels. Some studies in the literature also revealed similar findings (Özmaden, 2019; Yaşartürk and Bilgin, 2019; Yerlisu Lapa, 2013). It can be suggested that as individuals' life satisfaction levels increase, so do their leisure satisfaction levels. Nevertheless, there was no statistically significant relationship between job performance and leisure satisfaction.

Lastly, women's job performance levels were higher than men's. Although married participants' life satisfaction and job performance were higher than singles, this difference was not significant. Similarly, although regular laborers' life satisfaction and job performance were higher than contract laborers, this difference was not significant. Although both life satisfaction and job performance of those with 11-15 hours of weekly leisure were high, the difference was not statistically meaningful. Finally, it can be claimed that as job performance and leisure satisfaction increase, so does life satisfaction.

\section{REFERENCES}

Agyar, E. (2014). Contribution of perceived freedom and leisure satisfaction to life satisfaction in a sample of Turkish women. Social Indicators Research, 116, $1-5$.

Alessandri, G., Borgogni, L., Truxillo, D.M. (2015). Tracking Job Performance Trajectories Over Time: A Six-Year Longitudinal Study, European Journal of Work and Organizational Psychology, 24(4), 560-577.

Anitha, J. (2014). Determinants of employee engagement and their impact on employee performance. International Journal of Productivity and Performance Management, 63(3), 308-323.

Antaramian, S. (2017) The İmportance of Very High Life Satisfaction for Students' Academic Success, Cogent Education, 4(1), 1-10.

Argan, M., Argan, M.T., Dursun, M.T. (2018). Examining Relationships Among WellBeing, Leisure Satisfaction, Life Satisfaction, and Happiness. International Journal of Medical Research \&Health Sciences. 7(4), 49-59.

Aslan, N., Cansever, B.A. (2016). The Behavior of the Turkish Prospective Teachers. Higher Education Studies 6(2), 84-98.

Azaiza, F., Rimmerman, A., Croitoru, T., Naon, D. (2011). Participation in leisure activities by Arab Adults with intellectual disabilities living in the community. International Journal of Social Welfare. 20(1), 97-103.

Beard, J. G., \& Ragheb, M. G. (1980). Measuring leisure satisfaction. Journal of Leisure Research, 12, 20-33.

Borman, W. ve Motowidlo, S. (1997). Task Performance and Contextual Performance: The Meaning for Personal 
Selection Research. Human Performance, 10(2), 99-109.

Bozer, A. ve Yanık, A. (2020). Üniversite Çalıșanlarının Örgütsel Vatandaşlık Davranışı, İş Tatmini ve İş Performansı Arasındaki İlişki. Kırklareli Üniversitesi İktisadi ve İdari Bilimler Fakültesi Dergisi. 9(1), 125-143.

Chen, X. P., Eberly, M. B., Chiang, T. J., Farh, J. L., \& Cheng, B. S. (2014). Affective trust in Chinese leaders. Linking paternalistic leadership to employee performance. Journal of Management, 40(3), 796-819.

Cheng, E.H.P., Patterson, I., Packer, J., Pegg, S. (2010). Identifying the Satisfactions Derived from Leisure Gardening by Older Adults. Annals of Leisure Research. 13(3), 395-419.

Chick, G., Dong, E., \& Iarmolenko, S. (2014). Cultural consonance in leisure activities and self-rated health in six cities in China. World Leisure Journal, 56, 110-119.

Chick, G., Hsu, Y. C., Yeh, C. K., Hsieh, C. M., Bae, S. Y., \& Iarmolenko, S. (2016). Cultural consonance in leisure, leisure satisfaction, life satisfaction, and selfrated health in urban Taiwan. Leisure Sciences, 38, 402-423.

Cho, D., Post, J., Kim, S.K. (2017). Comparison of Passive and Active Leisure Activities and Life Satisfaction with Aging. Geriatrics \& Gerontology International. 18(3), 380-386.

Cho, H. (2019). Importance of Leisure Nostalgia on Life Satisfaction and Leisure Participation. The Service Industries Journal. 40(1-2), 90-109.

Choi, S.H., Fu, X. (2015). Re-examining the Dimensionality of Leisure Motivation and Leisure Satisfaction in a Multicultural Context: Evidence from Macau. Humanities \& Social Sciences Reviews, 3(1), 6-10.

Choi, S.H., Yoo, Y.J. (2017). Leisure Attitude and Satisfaction with Leisure and Life: Proposing Leisure Prioritization and Justification. World Leisure Journal. 59(2), 140-155.

Chun, S., Lee, Y., Kim, B., Heo, J. (2012). The Contribution of Leisure Participation and Leisure Satisfaction to Stress-Related Growth. Leisure Sciences. 34, 436-449.
Çakır, V.O., Şahin, S., Serdar, E., Parlakkılıç, Ş. (2016). An Examination of Public Employees the Level of Constraint of Leisure and Life Satisfaction. Journal of Tourism Theory and Research. 2(2), 135141.

Çelik, G., Tercan, E., Lapa, T.Y. (2014). Leisure Constraints and Leisure Satisfaction in The Recreational Activities of Employees with Disabilities. South African Journal for Research in Sport, Physiological Education, and Recreation. 36(2), 33-46.

Çöl, Güner (2008). "Algılanan Güçlendirmenin İşgören Performans1 Üzerine Etkileri”, Doğuş Üniversitesi Dergisi, 9 (1), 35-46.

Dattilo J, Schleien SJ (1994). Understanding leisure services for individuals with mental retardation. Mental Retardation 32(1), 53-59.

Dhani, P., Sharma, T. (2017). Effect of Emotional İntelligence on Job Performance of IT Employees: A Gender Study. Procedia Computer Science. 122, 180-185.

Diener, E., Emmons, R. A., Larsen, R. J., \& Griffin, S. (1985). The Satisfaction Eith Life Scale, Journal of Personality Assessment. 49, 71-75

Drakou, A., Kambitsis, C., Charachousou, Y., Tzetsis, G. (2006). Exploring Life Satisfaction of Sport Coaches in Greece. European Sport Management Quarterly. 6(3), 239-252.

Edginton, C.R., Jordan, D.J., DeGraaf, D.G., Edginton, S.R. (2005). Leisure and Life Satisfaction: Foundational Perspectives, 4th ed. McGrae-Hill: New York.

Eifert, E.K., Hall, M., Smith, P.H. ve Wideman, L. (2019). Quality of Life as A Mediator of Leisure Activity and Perceived Health Among Older Women. Journal of Women \& Aging, 31(3), 248268.

Erdogan, B., Bauer, T. N., Truxillo, D. M., \& Mansfield, L. R. (2012). Whistle While You Work: A Review of The Life Satisfaction Literature. Journal of Management, 38, 1038- 1083.

Ferrans, C. E. (1996). Development of a conceptual model of quality of life. 
Research and Theory for Nursing Practice, 10(3), 293-304.

George, D., Mallery, P. (2016). IBM SPSS statistics 23 step by step. Routledge.

Gökçe, H., \& Orhan, K. (2011). Serbest Zaman Doyum Ölçeğinin Türkçe Geçerlilik Güvenirlik Çalışması. Spor Bilimleri Dergisi, 22(4), 139-145.

Gürbüz, S., \& Şahin, F. (2016). Sosyal Bilimlerde Araştırma Yöntemleri: Felsefe. Yöntem, Analiz, Seçkin Yayıncılık: Ankara.

Hills, P., \& Argyle, M. (1998). Musical and religious experiences and their relationship to happiness. Personality and Individual Differences, 25(1), 91-102.

Holder, M. D., Coleman, B., \& Sehn, Z. L. (2009). The contribution of active and passive leisure to children's wellbeing. Journal of health psychology, 14(3), 378-386.

Iwasaki, Y., \& Mannell, R. (2000). Hierarchical Dimensions of Leisure Stress Coping. Leisure Sciences, 22(3), 163181.

Iyer, A., \& Jetten, J. (2011). What's Left Behind: Identity Continuity Moderates the Effect of Nostalgia on Well-Being and Life Choices. Journal of Personality and Social Psychology, 101(1), 94-108.

Janet D.N, Sirgy, M.J. Uysal, M. (1999). The Role of Satisfaction with Leisure Travel/Tourism Services and Experience in Satisfaction with Leisure Life and Overall Life. Journal of Business Research. 44(3), 153-163.

Jex, S. M., Thomas, J. L. (2003), Relations Between Stressors and Group Perceptions: Main and Mediating Effects, Work \& Stress, 17 (April), 158-169.

Kim, S., Sung, J., Park, J., Dittmore, S.W. (2015). The Relationship among Leisure Attitude, Satisfaction, and Psychological Well-Being for College Students. Journal of Physiological Education and Sport. 15(1), 70-76.

Kirkman, B. L. Rosen, B. (1999). Beyond SelfManagement: Antecedents and Consequences of Team Empowerment, Academy of Management Journal, Vol. 42 Issue 1, 58-74.

Koç, M.C. ve Er, Y. (2020). Leisure Satisfaction and Job Satisfaction: A
Research on Academics. African Educational Research Journal. 8(2), 329341.

Korotkov, D., Mcbean, H., \& Hamilton, L. (2011). Predicting leisure satisfaction: A comparative analysis of the agency and communion model with the five-factor model of personality. The American Association Behavioral and Social Sciences Journal, 15.

Kuppens, P., Realo, A., \& Diener, E. (2008). The Role of Positive and Negative Emotions in Life Satisfaction Judgment Across Nations. Journal of Personality and Social Psychology, 95(1), 66-75.

Kuykendall, L., Lei, X., Tay, L., Xheung, H.K., Kolze, M., Lindsey, A., Silvers, M., Engelsted, L. (2017). Subjective quality of leisure \& worker Well-being: validating measures \& testing theory. Journal of Vocational Behavior, 103, 1440.

Liang, J., Yamashita, T., Brown, J.S. (2013). Leisure Satisfaction and Quality of Life in China, Japan, and South Korea: A Comparative Study Using Asia Barometer 2006. Journal Happiness Studies. 14, 753-769.

Lin, H., Yu, B. (2015). Serious Leisure, Leisure Satisfaction and Subjective WellBeing of Chinese University Students. Soc. Indic. Res. 122, 159-174.

Mulki, J.P., Locander, W.B., Marshall, G.W., Harris, E.G., Hensel, J. (2008) Workplace Isolation, Salesperson Commitment, and Job Performance, Journal of Personal Selling \& Sales Management, 28(1), 6778 ,

Muzindutsi, P.F., Masango, Z. (2015). Determinants of Leisure Satisfaction Among Undergraduate Students at a South African University. International Journal of Business and Management Studies, 7(2), 1-15.

Ngai, V.T. (2005). Leisure Satisfaction and Quality of Life in Macao, China. Leisure Studies. 24(2): 195-207.

Özmaden, M. (2019). The Investigation of the Relationship between University Students' Leisure and Life Satisfaction Levels. International Journal of Progressive Education. 15(2), 91-103. 
Payne, L., \& Zabriskie, R. (2014). Understanding the Role of Leisure in Life Transitions. Journal of Park and Recreation Administration, 32(1), 1-6.

Prentice, C., Thaichon, P. (2019) Revisiting the job performance - burnout relationship, Journal of Hospitality Marketing \& Management, 28, 7, 807832.

Pressman, S. D., Matthews, K. A., Cohen, S., Martire, L. M., Schieier, M., Baum, A., Schulz, R. (2009). Association of enjoyable activities with psychological and physiological well-being. Psychosomatic Medicine, 71(7), 725-732.

Ragheb, M. G., \& Tate, R. L. (1993). A Behavioural Model of Leisure Participation, Based on Leisure Attitude, Motivation and Satisfaction. Leisure Studies, 12(1), 61-70.

Roe, R. A. (1999). Work performance: A multiple regulation perspective. In C. L. Cooper \& I. T. Robertson (Eds.), International review of industrial and organizational psychology. (Vol. 14, pp. 231-335). New York, NY: Wiley.

Rosa, C.D., Collado, S. Profice, C.C. and Larson, L.R. (2019). Nature-based recreation associated with a connectedness to nature and leisure satisfaction among students in Brazil, Leisure Studies, 38(5), 682-691.

Serdar, E. \& Demirel, M. (2020). Algilanan stres ile serbest zaman doyumu arasındaki ilişki: spor bilimleri öğrencileri Örneği. Atatürk Üniversitesi Beden Eğitimi ve Spor Bilimleri Dergisi, 22(3): 54-64.

Serdar, E., Ay, S.M. (2016). Üniversite Öğrencilerinin Katıldıkları Serbest Zaman Etkinliklerinden Tatmin Olma ve Algilanan Özgürlük Düzeylerinin İncelenmesi. İÜ Spor Bilimleri Dergisi. 6(2):34-44.

Serdar, E., Demirel, M., Demirel Harmandar, D., Donuk, B. (2018). Üniversite Öğrencilerinin Serbest Zaman Doyum Düzeyleri ile Mutluluk Düzeyleri Arasındaki İlişki. The Journal of Social Science. 5(28), 429-438.

Shin, K., You, S. (2013). Leisure Type, Leisure Satisfaction and Adolescents'
Psychological Well-being. Journal of Pacific Rim Psychology. 7(2):53-62.

Smith, K., Freeman, P., \& Zabriskie, R. (2009). An examination of family communication within the Core and Balance Model of Family Leisure Functioning. Family Relations, 58, 79-90.

Tian, H.B., Qiu, Y.J., Lin, Y.Q., Zhou, W.T., Fan, C.Y. (2020). The Role of Leisure Satisfaction in Serious Leisure and Subjective Well-Being: Evidence from Chinese Marathon Runners. Frontiers in Psychology. 11, 1-15

Tsaur, S.H., Liang, Y.W., Hsu, H.J. (2012). A Multidimensional Measurement of WorkLeisure Conflict, Leisure Sciences, 34(5), 395-416.

Türkoğlu, T., Yurdakul, Ü. (2017). Mobilya Endüstrisinde Çalışanların İş Doyumu ve İş Performansı Arasındaki İlişkinin Araştırılması. Artvin Çoruh Üniversitesi Orman Fakültesi Dergisi. 18(1), 88-97.

Walker, G.J. \& Ito, E. (2017). Mainland Chinese Canadian Immigrants' Leisure Satisfaction and Subjective Well-Being: Results of a Two-Year Longitudinal Study. Leisure Sciences, 39(2), 174-185.

Yaşartürk, F., Akyüz, H., Karataş, İ., Türkmen, M. (2018). The Relationship Between Free Time Satisfaction and Stress Levels of Elite-Level Student-Wrestlers. Education Sciences. 8(133),1-11.

Yaşartürk, F., Bilgin, B. (2019). Üniversitede Öğrenim Gören Hentbolcuların Serbest Zaman Tatmin ve Yaşam Doyum Düzeylerinin İncelenmesi. International Journal of Contemporary Educational Studies. 4(2), 50-60.

Yerlisu Lapa, T. (2013). Life satisfaction, leisure satisfaction and perceived freedom of park recreation participants. ProcediaSocial and Behavioral Sciences, 93, 19851993.

Yetim, Ü. (1993). Life satisfaction: A study based on the organization of personal projects. Social Indicators Research, 29(3), 277-289.

Yurcu, G., Kasalak, M.A., Akıncı, Z. (2018). Turistlerin Boş Zaman Motivasyonu ve Tatminini Etkileyen Faktörler: Beldibi Örneği. MANAS Journal of Social Studies. 7(2), 518-536. 